\title{
Constituencies of Conflict and Opportunity: Land Rights, Narratives and Collective Action in Darfur
}

Jon D. Unruh

McGill University

Musa Abdul-Jalil

University of Khartoum

\begin{abstract}
Grievance-based narratives are a primary component of civil wars. While present among the general population affected by conflict, the variants held by the segment of the population most proximate to the armed factions--constituencies--play a primary role in the development and conduct of a conflict. Such narratives can coalesce around specific volatile issues and enable non-combatant constituencies to participate in the conflict through the use of specific 'legalities' or legal precepts. These legalities facilitate the engagement of sets of collective action that are opposed to those derived by constituencies of the opposing side. However such constituencies and their narratives are also where potential opportunity resides for peace-building, both during and subsequent to hostilities. This article looks at the case of Darfur to examine these ingredients, with a focus on land rights as the volatile set of issues around which narratives have developed. In Darfur, opposed narratives which maintain how and why groups claim and deserve access to land and territory, and how groups were unjustly displaced or excluded from lands (and hence power), became solidified and acted upon prior to the conflict to become a primary driver in the current war. In certain cases however narrative change has led to interaction between members of opposed constituencies for the purpose of exploring cooperative arrangements.
\end{abstract}

Keywords: War, land rights, Africa, tenure, collective action.

Running headline: Constituencies of Conflict in Darfur

\section{INTRODUCTION}

The development of 'narratives of grievance' have proven to be a powerful driver in the onset and maintenance of civil wars (eg., Collier and Hoeffler 2004; Berdal 2005; Herbst 2000; Saggar 2009). While analyses of armed conflicts and efforts to bring about their end most frequently focus on combatants and their violent actions (e.g. Stedman et al 2002; Hurwitz 2008; Holbrooke 1998; Laremont 2002; Humphreys and Weinstein 2008), this article argues that a significant opportunity resides within the narratives that consolidate around specific volatile issues held by constituencies connected directly to the armed factions. The paper posits that prior to and during armed conflict, such constituencies are able to operationalize narratives of grievance and the justifications they provide, by using specific 'legalities' (legal precepts--statutory, customary, religious, or hybrids) to pursue forms of collective action that come to be set against the constituency of the opposing side. The result is that collective action by one constituency then fuels ongoing narrative development, use of legalities and collective action by the opposed constituency. While these narratives solidify, become increasingly acute, and their oppositional nature be- 
comes highly problematic for durable peace, this is also where latent opportunities exist for peace-building, and for decoupling constituencies from combatant groups. Thus while narrative formation in conflict scenarios is not new, what is new here is a theoretical framework regarding how narratives are formed and used by constituencies (as opposed to combatants or the broader population), in interaction with legalities, collective action and a specific volatile issue, as well the potential for using this mix in peace-building.

The case of Darfur (Figure 1) is used to examine the narratives, collective action and legal vehicles of constituencies in an armed conflict context, with land rights being the volatile set of issues around which narratives have coalesced and developed. This mix of ingredients has not yet been been examined in the academic, policy or practitioner literature. The article also provides a new analysis about how such narratives can change, and be changed, including purposefully from the 'outside'; and how this can coax collective action away from violent confrontation and toward the beginnings of cooperative livelihood constructs among members of opposed constituencies. Subsequent to sections describing the definition and functioning of conflict-related constituencies, narratives, legalities, and collective action generally, the Darfur specific mix of these ingredients is described, beginning with methods of data collection and the land rights aspect of the problem. The final section then looks at the emergent potential of these ingredients in Darfur to engage in incipient forms of peace-building.

\section{INGREDIENTS: CONSTITUENCIES, NARRATIVES, LEGALITIES, COLLECTIVE AC-} TION, LAND RIGHTS

This section describes the primary ingredients with regard to how constituencies function in a civil war context, and their connection to the relevant literatures. For the purposes of this paper, constituencies, narratives, legalities and collective action are described in their armed conflict variation. While 'conflict narratives' does have a specific supporting literature, 'conflict constituencies', 'conflict legalities', and 'conflict related collective action' are not represented and so the proximate literature is presented in order to help build the conflict variation of these. The objective is to advance these new variants for use in conflict and war-torn contexts. While the use of several literatures (constituencies, narratives, legalities, collective action and land tenure) to help describe the various ingredients of the study can be complex, it is necessary in order to put together the various components of the overall problem. These literatures are outlined below.

\section{$\underline{\text { Conflict Constituencies }}$}

While constituencies are described in the conflict literature, they are defined along the same lines as in stable settings--a body politic, the general citizenry, or broadly as 'supporters' (e.g. Stedman et al 2002; Hoddie and Hartzell 2010; Collier and Sambanis 2005; Johnson 20011). This article instead defines constituencies in civil war contexts as the inhabitants of Darfur themselves do-the immediate civilian support base for the armed movements, providing them with legitimacy, shelter, materiel and recruits, and the primary participants in narrative formation and development. The fieldwork reveals that this is a smaller group than the population of all sympathizers and supporters; or all people who are co-ethnic, co-religious or co-producers (i.e., farmers, pas- 
toralists) of the combatants, although constituencies would be comprised of individuals belonging to these groups.

At the same time it constituencies are broader than what might be termed 'partisan'. Those spoken to in Darfur indicate that while members of constituencies can find themselves obligated to armed factions, one of their primary characteristics is that they have suffered at the hands of opposing factions and their constituencies-loss of lives, livelihoods, land, property, crops, livestock and economic and political standing and opportunity. And while not all who have suffered such loss belong to constituencies, the fieldwork reveals that those that have suffered the most usually do. The interviews in Darfur also indicate that such constituencies usually benefit directly from specific activities connected to combatants, such as certain gains made in the conflict and in any peace negotiations, and as secondary occupants or resource users on land taken from their original occupants belonging to opposed constituencies and their broader communities.

The role of such constituencies is important with regard to the conduct of civil wars. Arguably it is the constituency - narrative combination which initially gives rise to an armed movement. In this regard there is not an explicit cause and effect relationship between narratives and constituencies. They operate instead in a form of simultaneity, whereby there is interplay and mutual development between them. This occurs as the accumulation and aggravation of grievances produces narratives that appeal to those that are aggrieved (constituency). At the same time a newly forming constituency continues to develop the relevant narrative. And while the individuals involved in such narrative development may become combatants, based on the fieldwork in Darfur, during the course of the conflict ongoing narrative maintenance and its further development continues to reside primarily with the constituency and less so with the combatant group in question-who instead become more focused on the immediacy of military objectives. However there is often an intentional blurring between constituencies and combatants. In the Darfur case, because the rebel fighters were (and are) able to hide among the constituency population who give them shelter, the government response was to encourage the Janjaweed to attack the constituency directly, with the promise to the Janjaweed of being able to keep the land they 'liberated'. The Janjaweed of course was already familiar with who would likely be with the constituency attached to the rebels, due to their aggrieved history with them (see section below on 'The Land Rights Problem'). Tiefenbrun (2011) notes more generally that this intentional blurring of the distinction between combatants and a civilian component of the population (with or against the acquiescence of local populations) is one of the fundamental precepts of asymmetrical warfare. Thus the relationship described here between combatants and non-combatants is different than that described by Weinstien (2006) where the relationship is on how non-combatants are recruited, or 'join' insurgent groups and counter insurgent efforts (also Humphreys and Weinstein 2008). In the present work 'joining' an insurgent movement is more nuanced than simply becoming an combatant or not.

\section{Conflict Narratives}

The present examination posits that narrative development among emergent constituencies prior to a conflict, occurs as negative events and processes regarding certain volatile issues come to be 
seen as being connected to specific groups perceived to be responsible. Such groups can be ethnic, religious, linguistic, aligned along production systems (pastoralist, agriculturalist), or a mix of these. These events and processes can include exclusion; discrimination; armed encounters; dislocation; secondary occupation; claiming of lands; destruction of property, crops and livestock; and ethnic, religious, linguistic or livelihood 'cleansing' in a variety of forms. Over time these perspectives spread, find fertile ground among others who feel similarly aggrieved, and can become both more simplified and acute. In aggregate these produce collective or shared narratives of injustice which then serve to rationalize certain responses (Toal and Dahlman 2011; Malkki 1995). Toal and Dahlman (2011) describe for Bosnia one of the processes by which this narrative solidification occurs; whereby over time citizens attached to opposed sides became embedded in separate information networks which led to their occupying different interpretive worlds--an observation relevant to the findings from Darfur. Similarly Malkki (1995) writing about the Burundi and Rwanda conflicts, notes that narratives become reinforced as events, relations and processes come to be interpreted along certain lines by evoking a collective past. Thus narrative formation by emergent constituencies predates armed conflict and in many cases armed factions are derived from segments of the aggrieved pre-conflict constituency population.

Such collective narratives can then become a kind of framework or 'blueprint' for the emergent constituencies (Malkki 1995) that can take on a 'juridical style' of oral narrative (Rodegem 1973; Lemarchand 1970); especially when actual legal precepts are interpreted within such a framework. These narratives can represent a collective history along certain lines of interpretation (Malkki 1995); what Comaroff (1985) terms 'event history', and Baird and Le Billon (2012) call 'politicized memories'. While frequently not well aligned with actual history, narratives in a conflict context are often constructed in opposition to other interpretations of history regarding the same issues (Malkki 1995). And in reality this "oppositional process of construction" (Malkki 1995:55) is to a large degree the purpose of conflict narratives. The 'narrative standardization' of events, processes and relations along certain lines--also noted among Hutu refugees in the $\mathrm{Bu}$ rundi conflict (Malkki 1995) and in the Northern Ireland conflict (Feldman 1991)--then contribute to the structuring of social action (Malkki 1995). Mayer (2006:1) argues that "shared narratives, $[\ldots]$ are the fundamental human device for enabling communities to act collectively". While a particular line of interpretation of current and historical events, processes and social relations is fundamental to collective narrative formation, such formation is greatly facilitated in cases where there existed previous to the war, significant confusion, disagreement, ambiguity, lack of information and rumour over key historical developments and understandings of societal structures surrounding certain conflictive issues (Abdul-Jilal and Unruh 2013). Such ambiguity then allows for multiple interpretations to flourish.

This paper builds on these understandings of narratives to argue that conflict narratives often coalesce around specific highly problematic issues which resonate strongly with grievances held by a portion of the broader population prior to the conflict, and then become aggravated to become volatile and then explosive in the lead-up to and during the conflict. In Darfur a primary set of issues around which narratives have developed--and a primary cause of the war--is land rights. 
This paper argues that for Darfur the complex problem of land rights has become a framework through which grievance-related history and contemporary events and processes are interpreted within the constituencies of both sides of the conflict.

\section{Conflict Legalities}

While narratives alone can be powerful motivators for collective action by constituencies in conflict scenarios, they become particularly powerful, and more easily operationalized, when connected with a 'legal vehicle' as a means of expression--as observed in Darfur. Of utility in this context are certain interpretations of legal precepts--statutory, customary, religious, or hybrids-which readily connect with currently held narratives. Such a construct can provide a powerful rationalizing or justifying influence on specific forms of collective action. While Mayer (2006:11) notes that, "institutions enable collective action by socializing individuals to behave in ways that further the collective", here it is argued that behaviours (actions) that are seen to have a legal (institutional) basis, provide a legitimizing link between narratives and certain forms of collective action. This is important, and a new aspect of the narrative - conflict relationship, because unlike combatants, who usually operate in a much more visceral, shortsighted domain of survival, violence and the attainment of military objectives indicative of battlefield encounter, constituencies use different tools for their participation in the conflict or else risk becoming combatants. Toal and Dahlman (2011) note that law and legal institutions were used extensively to operationalize narratives of ethnic cleansing in the Bosnian war. And the ongoing discussion regarding 'lawfare', or the use of law in warfare, provides numerous examples of a similar concept, albeit focused on statutory law only (e.g. Dunlap 2008; Tiefenbrun 2011; Altertus and Kaplan 2012) and not customary, religious and hybridized informal laws, as examined here.

\section{Collective Action in Conflict}

Collective action in a context of armed conflict is newly specified here as comprising a variety of actions that are justified, encouraged, and initiated by the narratives of opposed constituencies. A good deal of work has been done on collective action generally (e.g. Ostrom 1998; Porta et.al. 2009; Garrison 1992), including with regard to land and property rights (e.g. Mardon 2005; Agrawal and Ostrom 2001), and armed conflict (e.g. Wood 2003; Bellow and Miguel 2009; Kalyvas 2006). While a significant component of the collective action literature focuses on the forms of direct cooperation needed, of interest here is a broader conception of collective action in which participants do not always communicate with regard to specific actions, but are nonetheless aligned and know of commonly held narratives and the types of action connected to them. This is more in line with Mayer (2006), and Olson (1965) whereby collective action is directly tied to and operates off of narratives in a broader domain than exclusively intentional cooperation. In this context direct cooperation is de-emphasized, and the centrality and ubiquity of narrative in the conduct of collective action is emphasized (Mayer 2006).

\section{The Land Rights Problem}

In Darfur the land rights aspect of the conflict is acute and a driving force of narrative formation and collective action. While an elaboration of conflict over resources in Darfur has been presented elsewhere (e.g., Suiliman 2011; Olsson and Siba 2009; Unruh and Abdul-Jalil 2012), here the 
land rights that undergird the conflict is the focus. Widely regarded as one of the root causes of the war, land rights for the different groups involved are highly complex, emotive, contentious, and volatile (e.g. Flint and De Wall 2008; Abdul-Jalil 2007; Suiliman 2011; Concordis 2007). In one of the most severe manifestations of the land rights problem, certain Arab pastoralist groups were easily recruited into the Janjaweed for two primary reasons, land and money (Flint 2009).

While the cattle herding Arab groups occupying most of southern Darfur (southern Rezeigat, Habbania, Taisha, Beni Halba) have their own Dars, the Arab camel nomads of North and West Darfur do not (Abdul-Jalil 2008). This was partially due to the fact that the granting of tribal Dars during the sultanate era favoured larger tribes, but as well because in the past permanent forms of land claim were not important for nomadic pastoralists, who depended instead on transient rights of access. This pattern of land relationship constitutes one of the fundamental ingredients of the current civil war because control over land and political participation (hence power) are inseparable in Darfur. The land-power nexus translates directly into a variety of rights, political positions and livelihoods, as well as human security. The land tenure system operating within the Dars functions off a framework of Sultanate era land grants or 'hakura'. Thus the hakura tenure system became the prevailing customary system over most of contemporary Darfur (AbdulJalil 2006; O’Fahey and Abu Salim 2003).

In recent decades the combination of drought and population growth has led Arab pastoralist groups to move increasingly southward onto land in which the hakura land tenure system of the sedentary agriculturalists operate (Young et al 2005; Khalid 1999). And while prior to the war they had been accommodated in the Dars and within the hakura system as guests in fairly symbiotic relationships with sedentary agriculturalists, they have always been unable to fully participate in the tenure system and hence the political system. Thus while the hakura system does allow guests to enjoy land access, and engage in agricultural and pastoral production on an individual and village basis, their representation in the political system is limited to the mid-level position of Omda, with the much coveted higher position of Nazir (Paramount Chief) kept unattainable (Abdul-Jalil 2008). As a result their political participation in society involving hakura practicing tribes is significantly limited, and has prevented them from pursuing what they believe to be legitimate aspirations to rights, opportunities, and political development.

With such partial participation in the customary system, tenure insecurity was a problem for the northern pastoralists, such that fears about losing land access then drove the search for alternatives in statutory law, Islamic law and forms of resistance and confrontation. Widespread pursuit of such alternatives as a form of collective action within the hakura administered areas prior to the war then degraded the hakura system itself so that it had difficulty functioning effectively. Not surprisingly those indigenous to the hakura system resisted this, also in a confrontational way. Thus narrative formation around land issues has a significant history in the region. In the years just prior to the war, the Arab pastoralist demand for land rights became critical, and is to a large degree the reason for the government's ease of recruitment and support of the Janjaweed counterinsurgency (Flint and de Waal 2005). Landless Arab pastoralists form the north saw an opportunity to gain secure land access and hence greater political power. Interestingly Arab pas- 
toralist groups from the south that already had land, attempted to stay neutral in the conflict, and were not able to be recruited to become Janjaweed (DAa2-12 2009).

\section{DARFUR CONSTITUENCIES}

Two broad constituencies are examined by the paper--one on either side of the conflict. Thus the various tribes noted in the text are connected to one of these constituencies, usually depending on their primary production system--pastoralist or agriculturalist. Figure 2 illustrates the relationship of the Arab pastoralist constituency to both the Janjaweed combatants and the broader pastoralist population. The combatant group is numerically the smallest and is comprised primarily of the various Janjaweed militias along with government troops. The constituency group is larger than the combatant group, but significantly smaller than the broader population. This constituency comprises, 1) the 'secondary occupant' group--Arab pastoralists who occupy lands that have been forcibly emptied of their original sedentary agriculturalist inhabitants, and who would not have been able to do so without connections to the Janjaweed; 2) aggrieved Arab pastoralists whose attempts at gaining fuller political participation and sufficient land access for grazing and watering purposes have been thwarted by farmers and believe they have suffered as a result; and, 3) those pastoralists or their kin that perceive they or their group have been wronged by members of the agriculturalist population as a result of their second class status. The primary desires of this constituency are land access, political participation and hence greater power, along with retribution for perceived wrongs done to them personally, to kin, or to the broader Arab pastoralist group. The broader population comprises nomadic pastoralists and agro-pastoralists who are likely better off; or who along with environmental refugees are fleeing progressively more difficult livelihood scenarios in the Sahara and Sahel, and are further away, less affected or aggrieved by the conflict and land rights problems; or who are less able for a variety of reasons to participate in the constituency group (ANGO11-12 2009).

Figure 3 illustrates the relationship between the same three components on the sedentary agriculturalist side of the conflict. The rebel armed factions include various militias within the Sudanese Liberation Army (SLA) and the Justice and Equality Movement (JEM), along with other movements who variously split or recombine over time. This constituency comprises the several hundred thousand internally displaced persons, along with refugees, villagers at risk of forced displacement, and villages that shelter rebel combatants. The primary desire of the constituency is to obtain, 1) their land back from which they have been dislocated, 2) security from the depredations of the Janjaweed and armed pastoralists, and 3) compensation and forms of retribution on the Janjaweed, secondary occupants, and government. The broader population consists of most sedentary agriculturalists and certain agro-pastoralists who still have their land and a greater degree of security, along with urban dwellers connected to farmers as kin, and the trading sector.

\section{METHODS}

Research was conducted in December of 2009 and January of 2010 with an in-depth case study. The case study used a mixed method approach (Greene et al 1989) comprising a legal analysis that included statutory, customary and Islamic law along with the Darfur peace accords; a qualitative survey of key informant semi-structured interviews and focus groups; as well as an in- 
depth literature review that included the position statements of the armed factions, along with the academic, NGO, donor, and UN literature. The mixed method approach is most appropriate for unstable socio-political settings where a quantitative survey and other forms of sampling that rely on stable populations are not possible. The mixed method approach also facilitates the triangulation of different results, in this case from the legal analysis, the key informant survey, focus groups and the literature review.

The semi-structured interview and focus group fieldwork was conducted in December of 2009 and totalled 196 individuals. Semi-structured interviews were conducted in Khartoum and focus group and semi-structured interviews were conducted in the towns and outlying IDP (internally dislocated person) camps of Nyala in South Darfur, and El Fasher in North Darfur. In Khartoum 36 interviews were conducted in order to obtain information relevant to the conflict. These took place with people who were from or familiar with the region, or had an impact on the region through the implementation of laws, policies and the peace process; as well as those involved in analysis of the conflict and the conduct of the war. They included personnel with the Ministry of the Environment and Urban Settlement, the former governor of West Darfur, the former Minister of International Cooperation and Commissioner of North Darfur, the Darfur Lawyers Association, the Shura Council, Sudanese academics and UN officials. These interviews covered topics regarding the history of the conflict as perceived by different groups; access to and competition over a variety of resources; the different international, national, and local actors, interests and organizations and their activities; the different attempts at engaging a peace process; IDP and secondary occupant issues; land rights; legal aspects involving customary, statutory and Islamic law; national level and Darfur institutions--customary and statutory; the conduct of the war; infrastructure; politics; and tribal issues.

In Nyala and its surroundings in South Darfur (Figure 1), focus groups of IDPs were conducted in an IDP camp setting; and with elders of the Native Administration. These totalled 58 people. The focus groups covered topics including, IDP and secondary occupant issues; the functioning of Darfur customary institutions and their interaction with state institutions; the prospects and different approaches for peace; how the war is conducted; narratives of the different groups; and the different groups active in the war. In addition 41 semi-structured interviews were conducted with IDP representatives, members of the UNDP Community Reconciliation project, members of the Darfur Land Commission, local NGOs, members of the Native Administration, government ministry officials, UN personnel, members of the Compensation Commission, and tribal and religious leaders. The semi-structured interviews covered subject matter that included, land rights; IDP and secondary occupant issues; Islamic laws and institutions; customary leadership; government, NGOs, and customary organizations and institutions; history of the conflict; land boundaries and land organization; the narratives of different groups; laws--statutory, customary and Islamic--and their role in the conflict; agricultural and nomadic livelihoods; and the conduct of the conflict by different actors and groups.

In El Fasher and its surroundings in North Darfur (Figure 1), 41 key informant interviews were conducted. These included individuals with the Ajaweed Peace and Reconciliation Group; min- 
istry officials; Paramount Chiefs; the Peace and Reconciliation Council; the Darfur Development and Reconstruction Agency; the Darfur - Darfur Dialogue Committee; academics from the University of El Fasher; UN officials with FAO, UNDP, the UN Rule of Law Programme, UN HABITAT and the UN Resident Coordinators Office; IDPs and secondary occupants; and local community elders. These interviews covered the topics of, customary, statutory and Islamic law and their uses and problems; land rights; the conduct of the war by different groups and actors; agricultural and nomadic livelihoods; the functioning of local institutions; the peace process; tribal issues; the narratives of different groups and their development; customary leadership structure; and the prospects for recovery. In addition focus groups were conducted with a total of 13 people and included IDPs, local academics, and ministry personnel. The topics covered included, IDP and secondary occupant issues; the peace process; land rights; legal aspects--customary, statutory and Islamic; development issues; and the conduct of the war by different groups.

\section{TENURE NARRATIVES IN DARFUR}

\section{The Arab Pastoralist Narrative}

The land narrative of the Arab pastoralist constituency has at its foundation a number of historical injustices which are perceived to be ongoing, and are used to justify current actions against sedentary agriculturalists--including constituency support for 'liberation' of lands by the Janjaweed. These injustices exist as a sequential set of scenarios that seek to explain why the Arab pastoralist population of northern Darfur are essentially landless today. They begin in the early Sultanate period when nomadic populations were left out of the creation of Dars and the allocation of hakura by the early Sultans. The nomads did not have their own Sultans at the time who could have organized Dars, and the existing Sultans belonging to the sedentary tribes believed the nomads didn't need land due to their transient lifestyle, which included annual migrations into the southern areas. Thus according to this narrative, when the Sultans created the Dars and granted hakura, they took land out of access, use, and possible subsequent claim and ownership by Arab pastoralists, essentially depriving them of these lands (DAb2-12 2009). During the colonial period the British used the hakura land system in their indirect rule approach to colonial government, and dealt primarily with the hakura leadership, further solidifying the hakura system. This solidification included denying Arab pastoralists the creation of their own Dars and hakura during the colonial period because the existing hakura leadership at the time believed this would have taken land away from the sedentary agriculturalist population (O'Fahey 2008; Flint and de Waal 2008).

This narrative also holds that Arab pastoralists have been marginalized and their interests and problems (especially lack of land) ignored by successive independence governments. As an example of this perspective, statutory laws about land for most of the independence period were not enforced in Darfur, allowing continued operation of the discriminatory hakura system. While pastoralists acknowledge their general movement south following decades of drought and land degradation, they believe they have historically been prevented from full participatory inclusion in existing hakura and Dars held by the sedentary tribes. Compounding the problem, in the 1960s the railway was established in Darfur, causing land values in the better areas to increase as 
farmers started growing vegetables and other cash crops for the market. This resulted in closing off many wadis from nomad use. This also contributed to the closure of some livestock migration corridors, further depriving pastoralists of land access as well as the ability to pursue annual migrations. As a result this constituency narrative holds that they deserve the lands that have been 'liberated' in the course of the war and that the government has told them they can keep. In their view they are engaged in a 250 year-old quest for land that was provided to others but denied to them (O'Fahey 2008). This perspective, while not well aligned with actual history, is so acute that "hakura has become a battle-cry of the Janjaweed" (O'Fahey 2008:136). The Arab-pastoralist constituency is also angered that the international community has both condemned their aspirations regarding their need for lands and political participation, and sided with the agriculturalists as the colonial government did in the past.

\section{The Narrative of the Sedentary Tribes - Adherents of Hakura}

The land narrative of the sedentary agriculturalist constituency has at its foundation that the hakura tenure system has been and continues to be under threat and prior to the conflict was disregarded and degraded by outsiders attempting to acquire land. The narrative holds that Arab pastoralists and the government prior to the war were actively taking over their land using statutory and Islamic law, and in the current war by violence. Prior to the conflict they feared that allowing full participation by the large numbers of outsiders in the hakura system would lead to eventual dispossession of lands.

The many agriculturalists who are currently IDPs or refugees are profoundly aggrieved that Arab pastoralists and others are secondary occupants on their land. In this regard the fieldwork found that within the broader narrative there exists variation in the degree that grievance, anger, and the desire for retribution toward secondary occupants are present as prominent ingredients. Those that have very recently been subjected to forced dislocation and violence tend to have a simple, highly grievance-based narrative that holds retribution as a priority. The trauma and disorientation of their dislocation is still very real to them, such that there is a significant barrier to imagining interaction with secondary occupants, particularly while the latter are still armed. Thus for many IDPs and refugees, their ongoing dislocation remains a rallying point for belligerent forms of collective action by the constituency, as evidenced by numerous specific events (e.g. RD 2013; IDMC 2009). By contrast for IDPs that were dislocated several years ago, their narrative can be less simplistic and vitriolic, and they can under certain circumstances be more open to the prospect of interaction with secondary occupants.

There is further variation within the narrative of the agriculturalist constituency along $\mathrm{Fur}-\mathrm{Za}$ ghawa tribal lines. While these two tribes occupy the same side in the conflict, there are divisions between the two. Some within the Zaghawa community believe their legitimate attempts to settle on new land is being thwarted by both the government and the Fur who are threatened by and jealous of their success as agropastoralists and traders (ZA 2009). On the other hand a portion of the Fur community see the Zaghawa as wanting a 'greater Zaghawa' empire with control over enormous holdings, including eviction of other groups who have long inhabited certain ar- 
eas (FR4-12 2009). Because the traditional Zaghawa occupied areas extend well outside of Darfur into adjoining countries to the north and west, the accusation of foreign involvement has assumed some currency in the Fur sub-narrative.

\section{DARFUR LEGALITIES}

The Role of Confusion and Ambiguity

The fieldwork found that confusion and ambiguity regarding a number of important aspects of land tenure institutions and legalities in Darfur is significant, deep-seated, and well predates the conflict. When this combined with a war-affected context, the different understandings and interpretations of important terms and concepts became readily aligned with different sides in the war to support specific narratives, justifications, and historical scenarios. For example, the term hakura is pervasively used with regard to the customary tenure system, but in a variety of ways. In some cases hakura is referred to as a subset of a Dar and given to a specific person, in other cases hakura is taken to mean the same area as a Dar. For some, hakura is more of a system of institutions (and not a specific land area) that should be variously reinstated, expanded, done away with, or outlawed, depending on the group (factions, constituencies, donors, government, ethnic groups). Still others take hakura to mean a form of ownership rights, while others see hakura as just the document attesting to the granting of land (with the earliest dating from approximately 1700) (Abdul-Jilal and Unruh 2013). In addition, information and understanding about many of the hakura themselves (as landholdings) exist as broad narratives which emerged well before the current conflict. These can be subjective and contradictory, particularly regarding how many there are, where they are, and what the boundaries are (Egemi 2009). The role of these prewar hakura narratives has become more pronounced currently, given that many hakura documents have been purposefully destroyed in the war.

Statutory law with regard to land in Darfur is also confused, in particular with regard to the tenurial concepts and definitions of hakura, tribal land, private property, Dar, and the property versus administrative nature of statutory and customary boundaries (Abdul-Jalil and Unruh 2013). As well there is ongoing confusion and incongruence with regard to the relevance of laws, the history of their application, and who they applied to and why. There is also a lack of availability of copies of the land-relevant statutory laws in Darfur. As a result what the law says and does not say is largely unknown and not verifiable in much of the region. Such ambiguity regarding laws and the limited ability to verify their content can then be used to support particular narratives and detract from others. This also means that some parts of relevant laws exist in society as rumour, which can then easily come to support a certain narrative (Unruh 2012). Home (2003) observes a similar phenomenon regarding multiple interpretations of important terms in the Israel/Palestine land law and how it has been carried out.

There is also ambiguity and room for multiple interpretations of Islamic law. Islamic law is fused with customary law in Darfur, as it is in much of the Muslim world (e.g. O'Fahey 2008; Sait and Lim 2006; Bowen 2003). The historical land documents granting hakura (Figure 4) to their original holders in the Sultanate era refer to Allah, the Qur'an, Islamic law, and Islamic precepts throughout (O'Fahey and Abu Salim 2003). Some of the hakura land titles (also referred to as 
deeds or charters) were actual waqf -granting documents (waqfiyya)--waqf being an Islamic law religious endowment of land or property--while others were 'waqf-like' to varying degrees in that they were given to religious figures and were intended to be continuously held by their descendants (O'Fahey and Abu Salim 2003). Still other hakura land deeds were charters of privilege granted to various holy clans (O'Fahey and Abu Salim 2003). As a result, a particular hakura deed with a significant amount of, or more powerful religious phrasing, could be considered more waqf-like than others. Thus a certain 'argument' in a legal sense, could be made that a particular hakura should be seen as more waqf-like given its phrasing, or mention of certain religious aspects, or the religious figure it was initially given to. However the Arab pastoralist constituency and the government sought to discount the establishment of such waqf-likeness-the government by no longer honouring hakura deeds as it once did, and the pastoralist constituency by supporting the targeting and destruction of the deeds by the Janjaweed in an attempt to reduce the customary legal basis for hakura claims (DDD10-12 2009). As O'Fahey (2008:136) notes, referring to these documents, "today they are weapons of war".

Other interpretations of Islamic law or legal precepts regarding land are also evident in Darfur, with one in particular having a significant role in the conflict. This interpretation begins with invoking, 'all land belongs to Allah' as in statutory law, but instead of proceeding from this interpretation to state control, it follows with, 'and is therefore open to any Muslim'. Thus various interpretations of Islamic law were and are used to justify claims to land in different ways to separate sets of people. Such selectivity regarding use of Islamic law is not new to the conflict. O'Fahey (2008) reports that in 2003 and 2004 the Janjaweed burned mosques, desecrated Qur'ans and killed Imams connected to the agriculturalists in an apparent attempt at creating a divide regarding Islam between themselves and the farming groups.

\section{Use of Legal Vehicles by Constituencies}

All constituencies to the conflict were and are able to use specific legalities as vehicles to facilitate progression from narratives to collective action. For the Arab pastoralist constituency there are two legal vehicles used collectively to obtain lands in the hakura controlled areas. The first is use of an interpretation of the 1970 Unregistered Land Act, and the second is use of an interpretation of Islamic law. For the agriculturalist constituency the variety of laws and institutions that are a part of the hakura customary tenure system were used.

\section{the Arab pastoralist constituency}

The 1970 Unregistered Land Act stands out as a primary problem in the Darfur conflict. This law stipulates that all unregistered land is government property and therefore open to reallocation by government. In Darfur however very little land was registered due to the lack of dissemination of the law and the lack of services for surveying and processing applications (Abdul-Jalil and Unruh 2013). Thus the law asserted government ownership over lands already claimed by the haku$r a$ system. As issues surrounding the partial participation in the hakura system grew more severe for Arab pastoralists and some Zaghawa, they increasingly sought to claim land rights under the 1970 law, ignoring the hakura approach to guest accommodation for newcomers. Instead they 
argued that such land belonged to the government, and so could be given to them by the government. The many conflicts that the resettled Zaghawa have had with the Fur in the eastern goz (stabilized sand dunes used for agriculture), south of El-Fasher in the mid-1980s, were due to the repercussions of the 1970 law.

The pastoralist constituency also used the interpretation of Islamic law noted previously that 'all land belongs to Allah', thereby allowing any Muslim to use it. This legality was used as a vehicle to justify taking over and claiming lands belonging to agriculturalists. Although Islamic legal scholars agree that the state can hold land in trust for the universal Muslim community, irrespective of national boundary, it applies only to 'plain land' (in its natural state) as opposed to land that is clearly occupied and used (Sait and Lim 2006).

\section{the agriculturalist constituency}

While the hakura tenure system always advantaged native practitioners over migrants and guests, once the war was underway the customary laws of the system were used to refuse rights of land access and use to pastoralists, and to evict and revoke rights for many pastoralists who already had been granted them as guests. In a further 'legality' response to pastoralist attempts at land claim, the fieldwork learned that a local conference convened by prominent members of the hakura system determined that land cannot be given to outsiders if it is taken from those native to the area. And since all land in Darfur is claimed in some way by individuals and groups native to the hakura system, it essentially meant that no land would be available under this construct. Important in the current conflict context, is the hakura rule that good relations are critically important to obtaining and keeping land access and use rights as a guest within the hakura system. And since the initial intention of the Arab pastoralist constituency in moving onto land in the context of the conflict was belligerent, this violates the 'good relations' precept under hakura law. A Paramount Chief noted during the fieldwork that within the old hakura title documents it is clearly stated 'do no harm to neighbours', and 'with good neighbourly relations', and that such statements are still taken very seriously (NASD6-12 2009).

\section{COLLECTIVE ACTION IN DARFUR}

While a clear form of collective action in a context of armed conflict is the violent interaction between groups of combatants, in the Darfur case combatant groups also engage the constituent and broader population groups attached to the opposing side. This results in a range of outcomes that include, loss of life, forced dislocation, razed villages and crops, killing of livestock and taking lands. This also leads to people moving from the broader population group into the constituency group and from the constituency into the militias as they suffer depredations from the opposed combatant groups (DAb2-12 2009). Figure 5 illustrates this form of collective action by the combatants on the non-combatant segments of the opposition.

The fieldwork found that as animosity increased between farmers and pastoralists (both prior to and due to the conflict), the constituencies of each side engaged in forms of collective action to cripple the ability of the opposed production system to function. This grew to become one of the primary aspects of the conflict, and further solidified the connection between the constituencies 
and the armed factions. The farmer constituency blocked migratory routes of the pastoralists, planted crops in the migration corridors, closed off water points for livestock, prevented pastoralists from grazing their livestock on farmland, fenced off grazing areas next to their farms, prohibited pastoralists who were passing through the area from collecting firewood, planted crops near water points that were previously kept uncultivated so as to be used by pastoralists for grazing, and evicted pastoralists who they previously allowed on their land (Figure 6). For their part the pastoralist constituency damaged crops with their animals by disregarding grazing rules. They also burned crops, dug wells without seeking permission from landowners, took over lands belonging to farmers, sold farmer's land while they were secondary occupants to third parties, and forced farmers to pay to be left in peace on their own land (Figure 6) (ZA4-12 2009). Secondary occupation on agricultural land by pastoralists as a form of collective action was a primary approach used by the pastoralist constituency to in-part cripple the agriculturalist production system (DS5-12 2009). However secondary occupants themselves can range from pastoralists who forcibly dislocate farming communities and who then settle on such lands with the intention of keeping them; to pastoralists (and others) who do not themselves dislocate the original occupants, but acquire the land from those who did. The agriculturalist constituency reacted to this large increase in crop damage and dislocation, especially near Jebel Mara (where the war began) (Figure 1), by burning the bush grazing areas around their crops so as to discourage entry into the overall area by pastoralists. The Arab pastoralist constituency then reacted by taking their herds directly into the unharvested standing crops to graze, and by burning farming villages. The farmers then reacted to this by killing livestock. There was also direct violence by members of the two constituencies who occasionally assaulted each other individually and in groups as they encountered each other on the landscape (NASD6-12 2009).

\section{LATENT OPPORTUNITIES}

The fieldwork found that constituencies of both sides know the situation is changing, and that the war will one day be over. Those interviewed on the ground in Darfur indicated that the enormous UN peacekeeping presence, the international condemnation of the Janjaweed and government actions during the war, the great pressure from outside and within Sudan for IDPs to return to areas of origin, the Doha agreement and the ICC indictment of the Sudanese president, have all had an influence on the narratives of the different constituencies. Thus segments of the constituencies are seeking to position themselves more favourably with regard to what the future may bring. While the secondary occupants doubt that they will be indicted by the ICC over their ties to the Janjaweed or government in the war, they do know the international community condemns their secondary occupation and is aligned against them, and is putting great pressure on the Sudanese government to act against the Janjaweed and their pastoralist constituencies. The fieldwork found that this context can influence the narrative of some secondary occupants, and has in cases encouraged them to seek forms of collective action that allow them to "hedge their bets' with IDPs in an attempt to improve their position and future prospects. A segment of secondary occupants appear to desire to reposition themselves with regard to the original occupants, so that at a minimum they are not prosecuted, targeted for retribution, or forced to pay compensation; and perhaps might be able to depart peaceably or even to engage in a productive relation- 
ship with the original owners until their departure or beyond. While belonging to the same constituency, secondary occupants comprise a variety of people and situations and can have, or can develop, a variety of sub-narratives. While not all secondary occupants are conducive to such 'repositioning', many apparently are (DA5-12 2009). Veening (2010) notes for Bosnia the effect of an internationally prosecuted warlord having a similar effect on local militia commanders, pushing them to re-calculate what they are doing and encouraging the emergence of the notion of non-guarantee of impunity on their part. Williams (pers. comm.) also observes for Bosnia the positive effect of introducing doubt in the minds of secondary occupants and the role this had on their expectations of continued occupation. Likewise de Soto (2002) notes for Peru that targeting the acute land issues of the constituency to the Shining Path insurgency, contributed significantly to the separation of the constituency from the actual combatants, due to a change in the way the former saw their position with regard to a new set of constraints and opportunities.

On the part of the IDPs, those interviewed indicated that they wish to be well positioned so as to regain their lands from secondary occupants as easily and securely as possible, with as little damage done to the land and other agricultural assets as possible (IDPa4-12 2009). While some IDPs indicated that they may desire to pursue retribution or compensation, at a minimum they desire a swift and unproblematic departure of the secondary occupants currently on their land, and that these not be replaced by other secondary occupants. In this regard IDPs understand that the departure of the current secondary occupants long before the original IDP owners are able to retake control, would risk the vacant land being occupied by others. One focus group indicated that some IDPs appear to be willing to derive temporary or other arrangements with current secondary occupants such as rent or sharecropping (with payment or produce going either to the IDP or secondary occupant) until conditions are more conducive to their return (IDPa4-12 2009). Still other IDPs appear willing to make similar arrangements over the longer-term as part of a reworked rural - urban livelihood (IDPb4-12 2009).

The fieldwork found a number of specific examples of such arrangements. In one case from Nyala, IDPs from a focus group indicated that they had successfully initiated talks with secondary occupants regarding use and rent of their land. In this case the secondary occupants would continue to occupy and farm the land, and pay a form of rent to the IDPs for the remainder of the conflict (IDPb4-12 2009). A second example (also from a focus group), is the role of preexisting (pre-war) relations between specific IDPs and individual members of Arab pastoralist groups who now occupy their land. In this case subsequent to the onset of the conflict and dislocation of agriculturalists, some pastoralists endeavoured to end up on the land of displaced agriculturalists whom they knew. In other cases livestock belonging to IDPs have ended up in the hands of known pastoralists. In still others discrete communication between secondary occupants and IDPs has facilitated agricultural harvest and/or livestock either being sold in the local market with a portion of the money going to the IDP owner; or the pastoralist explicitly continuing to take care of the animals and/or the land for the IDP (DA5-12 2009). In one specific case, a pastoralist took over an orchard belonging to a displaced farmer whom he knew. The pastoralist would bring produce from the orchard to market to sell, giving a portion of the money to the IDP. Both parties engage in the understanding because they are interested in a potential post-conflict 
arrangement of mutual benefit, and an avoidance of problems resulting from either the IDP attempting to reacquire the land while the conflict is still underway, or the known secondary occupant departing and an unknown occupant taking over the land with the prospect of permanent claims or an exploitive or abusive arrangement emerging. As it stands, the IDP in question stays dislocated and resident in a camp or elsewhere, and the secondary occupant remains on the land ostensibly until it is safe for the IDP to return (DDD10-12 2009). In another example, members of constituencies from opposing sides have cooperated toward keeping the roads from Jebel Mara (Figure 1) open and safe for truck transport for the purpose of moving agricultural produce to market and the opportunities for revenue this offers (DNGO10-12 2009).

In addition, there are various locally derived agreements between certain Janjaweed militias and rebel factions in Darfur, particularly beginning in 2005 (DNGO10-12 2009). Whether these were the result of pressure from their own constituencies or not is unverified, but is likely due to the priority given to constituency concerns in the agreements. Flint (2009) describes four agreements between the SLA-Abdel Wahid and various Janjaweed militias, and two between JEM and different Janjaweed militias. Of these six agreements, five included Arab pastoralist land and property issues important to that constituency. One of these, the agreement between JEM and Musa Hilal's Janjaweed militia, came about primarily due to Musa Hilal's grievance that the government was not moving to support land rights as demanded by Arab communities (Flint 2009). Another, between the SLA-Abdel Wahid and the Rizeigat pastoralist constituency from al Da'ein, produced a signed document that included the re-establishment of transient rights of land access for pastoralists to Jebel Mara during the rainy season (Flint 2009). In contrast it is noteworthy that neither of the two internationally brokered peace agreements included Arab pastoralist land rights issues, nor were representatives of the constituencies invited to Abuja or Doha; the assumption apparently being that the leadership of the combatant groups represented their interests.

There is evidence from the fieldwork that local constituencies from opposed sides in the conflict in some cases have concluded their own 'peace agreements' with each other because they felt the combatant groups they are attached to no longer represented their interests (DNGO10-12 2009) (also Schlein 2011). Figure 7 is such an agreement between three constituencies of different tribes in eastern North Darfur involving lands and describes that they will live together peaceably (ANGO11-12 2009). The Berti noted in Figure 7 are a sedentary agriculturalist clan, the Meidob are traders and pastoralists, and the Zaiadiya are Arab pastoralists who also engage in some agriculture. The Berti and the Zaiadiya in particular have regarded each other as enemies in the conflict (Sudan Vision 2012).

\section{CONCLUSIONS}

While involving combatant groups in peace negotiations is an ongoing priority in bringing an end to armed conflicts, this article argues that internationally run peace processes must also improve ways to deal with constituencies, their narratives, and the legal vehicles they use, even prior to the end of hostilities. As opposed to focusing exclusively on the leadership of the combatant groups to sign a peace accord, this paper maintains that constituencies' narratives can be incen- 
tivized to move in certain directions, providing for new forms of collective action to emerge. Such forms may assist in moving constituencies or subsets of them away from hostilities, and particularly away from linkage with combatant groups. In a similar vein, Richmond and Mitchell (2012) provide a number of conflict cases regarding the role of 'everyday activities' and local agency in 'hybrid forms of peace'. In Darfur there are robust indications that such a prospect could be capitalized on. A 'conference' held in the Hamidiya IDP camp in North Darfur, involved representatives from fifty-three IDP camps (RD 2012). Among the items agreed to by the representatives of the camps was significant "regret" that the international community only recognized representatives of the combatant groups, such as those that were invited to be signatories to the Doha document, and not "other elements" (RD 2012). The representatives indicated that dealing only with such groups will not lead to a solution to the Darfur conflict, and "instead will increase problems and suffering" (RD 2012). Further, the IDP representatives blamed the JEM (a primary rebel insurgent group supposedly fighting on behalf of IDP farmers) of being behind plans to dismantle IDP camps, which the IDPs are very much against (RD 2012). Thus the narrative of the agriculturalist constituency appears to be shifting away from that held by some of the rebel combatants. In the Darfur case, different constituency groups from both sides in the conflict attempted to go to the Abuja and Doha peace talks on their own to express their views on the peace process--in part because they came to differ from the combatant groups who claimed to represent them (RD 2011).

It is well known that the land rights narratives of specific groups can be encouraged toward war, with Bosnia (Toal and Dahlman 2011), Rwanda (Corey and Joierman 2004), and Israel/Palestine (Gerner 1994) being vivid examples, but there are many. What is unappreciated and under-utilized by the international peace-building community, is the potential utility of constituencies and narratives (and components therein) in moving important segments of a civilian population away from combatants and toward peace. Different than pursuing ceasefires and peace negotiations-

which occur among combatants--or winning hearts and minds, which is intended to occur among the broader population, what is needed is greater overt use of 'constructive ambiguity' (e.g. Veening 2010) among constituencies. Such ambiguity is the space for constituency-based negotiations and alternative forms of collective action to be explored, involving room for maneuver and experimentation among individuals and groups. Such an approach would argue against pursuing clarity on every important issue among all sectors in peace-building as an assumed positive end. This is presently a difficulty for the international peace-building community. In the Darfur example as in others, it is the flexibility and ambiguity of informal relations (including tenure relations), not clarity, which allows for the elasticity needed for local derivation of 'on the spot' experimentation and cooperation, and which is more amenable to use by constituencies than it is by combatants and their leaders.

\section{REFERENCES}

Abdul-Jalil Musa. A. (2006). The dynamics of customary land tenure and natural resource management in Darfur. Land Reform, Settlement and Cooperatives, 2, 9-23. 
Abdul-Jalil Musa. A. (2007). Future prospects for Native Administration and local governance in Darfur. In A De Waal (Eds.), War in Darfur and the search for peace. Harvard University, Boston Global Equity Initiative.

Abdul-Jalil Musa, A. (2008). Judiya: A means for conflict management and peace-building in Darfur (in Arabic), paper presented at the Transitional Justice Workshop, Human Rights Section, UNAMID, El-Fasher, December.

Abdul-Jilal, M., Unruh, J. (2013) Land rights under stress in Darfur: a volatile dynamic of the conflict, War and Society, 32, 156-181.

Agrawal, A., Ostrom, E. (2001). Collective action, property rights and decentralization in resource use in India and Nepal. Politics and Society, 29, 485-514.

Altertus, M., Kaplan, O. (2012). Land reform as a counterinsurgency policy: evidence from Colombia. Journal of Conflict Resolution. Published online, 28 June

Ajaweed NGO, anon. (ANGO11-12) (2009) Key informant, 11 Dec.

Baird, I., Le Billon, P. (2012). Landscapes of political memories: War legacies and land negotiations in Laos. Political Geography, 31, 290-300.

Bellow, J., Miguel, E. (2009). War and local collective action in Sierra Leone. Journal of Public Economics, 93, (11-12) 1144-1157.

Berdal, M. (2005). Beyond greed and grievance-and not too soon... Review of International Studies, 31, 687-698.

Bowen, J. (2003). Islam, Law and Equality in Indonesia: An Anthropology of Public Reasoning. Cambridge: Cambridge University Press.

Collier, P., Sambanis, N. (Eds). (2005). Understanding Civil War: Evidence and Analysis - Europe, Central Asia, and Other Regions. Washington DC: The International Bank for Reconstruction and Development and the World Bank.

Collier, P., \& Hoeffler, A. (2004). Greed and grievance in civil wars. Oxford Economic Papers 56 563-595.

Comaroff. J. (1985). Body of power, spirit of resistance: The culture and history of a South African people. Chicago: University of Chicago Press. 
Concordis. (2007). Land use and tenure: A Key to sustainable peace in Darfur. Cambridge, UK: Concordis International.

Corey, A., \& Joireman, S. (2004). Retributive justice: the Gacca courts in Rwanda. African Affairs, 103, 73-89.

Darfur Academic-a, anon. (DAa2-12) (2009) Key informant, 2 Dec.

Darfur Academic-b, anon. (DAb2-12) (2009) Key informant, 2 Dec.

Darfur Academic, anon. (DA5-12) (2009). Key informant, 5 Dec.

Darfur NGO representative, anon. (DNGO10-12 2009) Key informant, 10 Dec.

Darfur - Darfur Dialouge representative, anon. (DDD10-12 2009) Key informant, 10 Dec.

Darfur Sheik, anon. (DS5-12) (2009) Key informant, 5 Dec.

Dunlap, C. (2008). Lawfare today: a perspective. Yale Journal of International Affairs, Winter: 146-154.

Egemi, O. (2009). Land tenure issues in Darfur. Nairobi, UN Habitat.

Feldman, A. (1991). Formations of violence: The narrative of the body and political terror in Northern Ireland. Chicago: University of Chicago Press.

Fur Respondent, anon. (FR4-12) (2009). Key informant interview, 4 December.

Flint, J. (2009). Beyond the Janjaweed: understanding the militias of Darfur. The Small Arms Survey, Geneva: Graduate Institute of International and Development Studies.

Flint, J., \& de Waal, A. (2005). Darfur: A short history of a long war. London: Zed Books: in association with International African Institute.

Garrison. W. (1992). The social psychology of collective action In A. Morris, \& C. Mueller (Eds.). Frontiers in Social Movement Theory. New Haven: Yale University Press.

Gerner, D. (1994). One land, two peoples: The conflict over Palestine. Boulder, CO, USA: Westview Press.

Greene, J., Caracelli, V., \& Graham, W. (1989). Toward a conceptual framework for mixedmethod evaluation designs. Educational Evaluation and Policy Analysis, 11, 255-274. 
Herbst, J. (2000). Economic incentives, natural resources and conflict in Africa. Journal of African Economies, 9, 270-294.

Hoddie, M., \& Hartzell, C. (2010). Strengthening peace in post-civil war states: Transforming spoilers into stakeholders. Chicago: University of Chicago Press.

Holbrooke, R. (1998). To end a war. New York: Random House.

Home, R. (2003). A 'irreversible conquest'? Colonial and postcolonial land law in Israel/Palestine. Social and Legal Studies, 12, 291-310.

Humphreys, M., \& Weinstein, J. (2008). Who fights? The determinants of participation in civil war. American Journal of Political Science, 52, 436-455.

Hurwitz, A. (2008). Civil war and the rule of law: Security, development, human rights. London: Lynne Rienner.

IDMC. (2009). Internal displacement: global overview of trends and developments in 2008. Geneva, Internal Displacement Monitoring Centre, Norwegian Refugee Council.

Internally Dislocated Persons-a, anon. (IDPa4-12) (2009) Focus group, 4 Dec.

Internally Dislocated Persons-b, anon. (IDPb4-12) (2009) Focus group, 4 Dec.

Johnson, D. (2011). The root causes of Sudan's civil wars: Truce or peace. Sufolk, UK: James Curry.

Kalyvas, S. (2006). The Logic of Violence in Civil War. New York: Cambridge University Press.

Laremont, R. (2002) The causes of war and the consequences of peacekeeping in Africa. Portsmouth, NH USA: Heinmann.

Lemarchand, R. (1970) Rwanda and Burundi. New York: Praeger.

Malkki, L. (1995) Purity and exile: Violence, memory, and national cosmology among Hutu refugees in Tanzania. Chicago: University of Chicago Press.

Mardon, M. (2005). Three essays on gender, land rights and collective action in Brazil's rural political economy. University of Massachusetts - Amherst: Dissertation.

Mayer, F. (2006). Narrative and collective action: The power of public stories. Paper presented at the American Political Science Association annual meeting, Philadelphia, September 1. 
Native Administration of South Darfur, anon. (NASD6-12) (2009) Focus group, 6 Dec.

O'Fahey, R., \& Abu Salim, M. (2003). Land in Dar Fur: Charters and related documents from the Dar Fur Sultanate. Cambridge: Cambridge University Press.

O’Fahey, R. (2008). The Darfur Sultanate: A history. New York: Columbia University Press.

Olson, M. (1965) The logic of collective action. Cambridge, MA: Harvard University Press.

Olsson, O., and Siba, E. (2009) Ethnic Cleansing or Resource Struggle in Darfur? An empirical analysis. Working Papers in Economics No. 417. Göteborg, Sweden: Department of Economics, University of Gothenburg

Ostrom, E. (1998). A behavioural approach to the rational choice theory of collective action: Presidential address American Political Science Association, 1997. American Political Science Review, 92, 1-22.

Porta, D., Kriesi. H., \& Rucht, D. (2009) Social movements in a globalizing world. Basingstoke: Palgrave Macmillan.

Radio Dabanga (RD). (2012) Sudan: unprecedented conference held in Hamidiya camp. Radio Dabanga, 6 Nov.

Radio Dabanga (RD). (2013) Biggest forced displacement in Sudan. Radio Dabanga 17 January.

Richmond, O., \& Mitchell, A. (2012) Hybrid forms of peace: From everyday agency to post-liberalism. New York: Palgrave-Macmillan.

Rodegem, F. (1973). Burundi: la face cachee de la rebellion. Intermediaire, 12-15, June, 15-25.

Saggar, S. (2009). Boomerangs and slingshots: radical Islamism and counter-terrorism strategy. Journal of Ethnic and Migration Studies, 35, 381-402.

Sait, S., \& Lim, H. (2006) Land, law, and Islam: Property and human rights in the Muslim world. London: Zed Books.

Schlein, L. (2011). Water scarcity root of Darfur conflict. VOA, June 11, 2011. http:// www.voanews.com/english/news/africa/Water-Scarcity-Root-of-Darfur-

Conflict-123688459.html.

Stedman, S., Rothchild, D., \& Cousens, E. (2002) Ending civil wars: The Implementation of peace agreements. Boulder USA: Lynne Rienner Publishers. 
Sudan Vision. (2012). Impact of conflict on Darfur's livelihood. Sudan Vision 53, June 26.

Suiliman, O. (2011) The Darfur conflict: Geography or Institutions? New York: Routledge.

Tiefenbrun, S. (2011) Semiotic definition of 'lawfare'. Case Western Reserve Journal of International Law, 43, 1-25.

Toal, G., \& Dahlman, C. (2011) Bosnia remade: Ethnic cleansing and its reversal. Oxford, UK: Oxford University Press.

Unruh, J. \& Abdul-Jalil, M.A. (2012) Land rights in Darfur: institutional flexibility, policy and adaptation to environmental change. Natural Resources Forum, 36, 274-284.

Unruh JD (2012) Land and legality in the Darfur conflict. African Security 5:105-128

Veening, W. (2010) Personal communication, Institute for Environmental Security, The Hauge, Netherlands, International Research Workshop on Collective Action, Property Rights, and Conflict in Natural Resources Management, June 28 - July 1, Siem Reap, Cambodia.

Weinstein, J (2006) Inside rebellion: The politics of insurgent violence. Cambridge UK: Cambridge University Press.

Wood, E. (2003) Insurgent collective action and civil war in El Salvador. Cambridge UK: Cambridge University Press.

Young, H., Osman, A., Akilu, Y., Dale, R., \& Badri, B. (2005). Darfur livelihoods under siege. Omdurman, Sudan: Feinstein International Famine Center Tufts University and Ahfad University for Women.

Zaghawa Association (ZA) (2009). Focus group, 4 Dec. 